\title{
NASIONALISME DALAM NARASI CERITA FILM (ANALISIS NARASI TZVETAN TODOROV PADA FILM HABIBIE \& AINUN)
}

\author{
Azis Maulana ${ }^{1}$, Catur Nugroho ${ }^{1}$ \\ ${ }^{1}$ Universitas Telkom
}

\begin{abstract}
ABSTRAK
Sebagai sebuah karya seni, film merupakan hasil dari proses kreatif berbagai unsur, di antaranya teater, seni musik, seni rupa, seni suara, dan teknologi dengan kekuatan gambar sebagai bentuk visualisasi. Penyampaian pesan film untuk penonton dapat dilihat dari sudut pandang narasi yang digunakan. Hal ini dikarenakan narasi berkaitan dengan cara bercerita, cara sebuah fakta dalam film disajikan atau diceritakan kepada penonton. Tzvetan Todorov memiliki teori narasi yang mengatakan bahwa sebuah film atau cerita memiliki bagian. Film Habibie \& Ainun menjadi film yang paling banyak ditonton di antara film-film sejenis yang ada di Indonesia. Jumlah penonton bioskop film Habibie \& Ainun hingga saat ini telah mencapai 4,5 juta penonton dan menduduki peringkat ketiga untuk film dengan jumlah penonton terbanyak sepanjang masa di Indonesia. Penelitian ini bertujuan untuk mengetahui prinsip nasionalisme dalam narasi cerita film Habibie \& Ainun dilihat dari analisis narasi pada bagian cerita awal, tengah dan akhir film. Penelitian ini menggunakan metode kualitatif dengan paradigma konstruktivisme. Hasil penelitian ini menunjukkan bahwa film Habibie \& Ainun merupakan film yang mengandung prinsip nasionalisme. Prinsip nasionalisme yang terlihat dalam narasi cerita awal yaitu prinsip kepribadian dan prestasi. Pada narasi cerita tengah terdapat semua prinsip nasionalisme yaitu kesatuan, kepribadian, kesamaan, kebebasan dan prestasi. Terakhir, prinsip nasionalisme pada narasi cerita meliputi prinsip persatuan dan kepribadian.
\end{abstract}

Kata-kata Kunci: Film, Cerita, Naratif, Nasionalisme, Todorov.

\section{NATIONALISM IN NARRATIVE OF A FILM STORY (ANALYSIS OF TZVETAN TODOROV'S NARRATIVE IN HABIBIE \& AINUN FILM)}

\begin{abstract}
As an artwork, film is a result of various elements creative process including theatre, musical art, visual art, sound art and technology with the power of pictures as its visualisation form. The delivering of a film message to viewers can be seen from the point of view of the narrative used. This is due to narrative has a relation to the way of storytelling, how delivering or telling facts in a film to viewers. Tzvetan Todorov has a theory saying a film or story has stages of structures. Habibie \& Ainun is a film with the most viewers among the same kinds of films in Indonesia. The number of Habibie \& Ainun viewer has reached 4.5 million to the present time and the film got the third rank as a film with highest viewer of all time in Indonesia. This research has an objective to recognise how the nationalism principles in the narrative of Habibie \& Ainun viewed by narrative analysis on the beginning, middle and end part of the film. The used-method of this research was quantitative method with paradigm of constructivism. The result of the present research indicates that Habibie \& Ainun contains of nationalism principles. The nationalism principles viewed in the beginning narrative are personality and achievement. In the middle narrative, the film contain of all nationalism principles, namely: unity, personality, similarity, freedom and achievement. In the last part, nationalism principles in the narrative comprise of unity and personality.
\end{abstract}

Keywords: Film, Story, Narrative, Nationalism, Todorov.

Korespondensi: Azis Maulana. Universitas Telkom, J1. Telekomunikasi, Sukapura, Dayeuhkolot, Bandung 40257.Email: maulanazis30@gmail.com 


\section{PENDAHULUAN}

(ANALISIS NARASI TZVETAN TODOROV PADA FILM HABIBIE \& AINUN)

Film merupakan salah satu bentuk komunikasi massa yang cukup populer di Indonesia saat ini. Memasuki kuartal ketiga tahun 2016, jumlah film Indonesia yang sudah beredar hingga saat ini di mencapai 80 film. Sebanyak 10 film telah ditonton oleh lebih dari 500 ribu penonton. Bahkan 7 dari 10 film tersebut berhasil menembus angka satu juta penonton. Sebanyak 10 film telah ditonton oleh lebih dari 500 ribu penonton. Bahkan 7 dari 10 film tersebut berhasil menembus angka satu juta penonton (Film Indonesia, 2016). Sebagai sebuah karya seni, film merupakan hasil dari proses kreatif berbagai unsur yang diantaranya adalah teater, seni musik, seni rupa, seni suara, serta teknologi dengan kekuatan gambar sebagai bentuk visualisasinya. Film selain sebagai alat untuk mencurahkan ekspresi bagi penciptanya, juga sebagai alat komunikator yang efektif. Sebuah film dapat menghibur, merangsang pemikiran, mendidik, melibatkan perasaan dan memberikan dorongan bagi para penontonnya, terlebih film juga bisa memberikan efek-efek negatif bagi penontonnya di kehidupan sehari-hari. Sebuah film yang merupakan salah satu media massa ini memiliki tiga fungsi utama yakni, (1) memberi informasi (to inform), (2) mendidik (to educate), dan (3) menghibur (to entertain). Selain ketiga fungsi utama tersebut, tiga fungsi lainnya dari sebuah media massa yakni, (4) mempengaruhi (to influence), membimbing (to guide), dan mengeritik (to critic) (Effendi, 1986). Pada hakikatnya informasi diartikan sebagai suatu rekaman fenomena yang diamati, atau bisa juga berupa putusan-putusan yang dibuat seseorang mendidik juga merupakan salah satu fungsi penting yang menjadi perhatian bagi masyarakat. Penilaian terhadap sebuah informasi yang disebarkan dari media massa ditentukan oleh seberapa besar tingkat edukasi yang disampaikan.

Nasionalisme adalah sebuah keinginan individu untuk mengabdi pada negara tempat ia lahir. Nasionalisme sendiri memiliki enam prinsip yang diyakini jika prinsip tersebut bersatu padu maka setiap hak warga negara bisa tercapai yakni, (1) hasrat untuk mencapai sebuah kesatuan (2) hasrat untuk mencapai sebuah kemerdekaan (3) hasrat untuk mencapai keaslian. (4) hasrat untuk mencapai sebuah kehormatan bangsa (5) adanya persamaan RAS (6) keinginan dan tekad bersama untuk melepaskan diri dari belenggu penindasan (Hertz, 1944). Indonesia sendiri merupakan sebuah negara yang merdeka dengan perjuangannya sendiri. Jiwa nasionalisme bagi seluruh masyarakat Indonesia sangat tinggi karena untuk merdeka dan mempertahankan kemerdekaan dari para penjajah harus dilalui dengan perjuangan yang berat.

Penyampaian suatu pesan kepada para penonton, dilakukan oleh pembuat film dengan berbagai macam cara. Penggambaran bisa bersifat kronologis, tematis atau dialetik. Dikemas sedemikian rupa agar pesan yang dimaksud dengan mudah tersampaikan. Penyampaian pesan film untuk penonton bisa (Estabook dalam Senova, 2016). Fungsi 
ProTVF, Volume 2, Nomor 1, Maret 2018, Hal. 37-49

dilihat dari sudut pandang narasi yang digunakan. Hal ini dikarenakan narasi berkaitan dengan cara bercerita, bagaimana sebuah fakta dalam film disajikan atau diceritakan kepada penonton. Tzvetan Todorov memiliki teori narasi yang mengatakan bahwa sebuah film atau cerita memiliki bagian. Bagian tersebut antara lain bagian awal, tengah dan bagian akhir. Penelitian ini ingin mengkaji bagaimana sebuah nasionalisme dalam film digambarkan berdasakan bagian-bagian yang ada dalam film tersebut (Eryanto, 2014).

Indonesia memiliki daftar-daftar film seperti film seperti Sang Pencerah, Darah Garuda, Tendangan Dari Langit, Soegija, Habibie \& Ainun, $5 \mathrm{~cm}$ dan Soekarno: Indonesia Merdeka, merupakan film-film Indonesia yang mengandung unsur nasionalisme didalamnya. Diantara film-film tersebut, film Habibie Ainun menjadi yang paling banyak di tonton. Jumlah penonton bioskop film Habibie \& Ainun hingga saat ini telah mencapai 4,5 juta penonton dan menduduki peringkat ketiga film dengan jumlah penonton terbanyak sepanjang masa di Indonesia. Hal tersebut menunjukan bahwa ketertarikan terhadap film Habibe \& Ainun tersebut sangat tinggi dibandingkan film-film sejenis lainnya. Melalui penelitian mengenai film Habibie \& Ainun diharapkan bisa menggugah jiwa nasionalisme yang ada didalam diri. Sesuai dengan fungsi yang dimiliki oleh media massa bahwa sebuah media massa termasuk film memiliki fungsi informatif, edukatif dan hiburan. Terlebih film ini merupakan sebuah kisah nyata dari seorang
BJ Habibie sehingga hal-hal yang terjadi di dalam film berdasarkan kejadian nyata. Film Habibie \& Ainun menggambarkan sebuah nasionalisme melalui adegan-adegan yang di tampilkan dalam film tersebut.

\section{Komunikasi Media dan Khalayak}

Komunikasi massa adalah proses penyampaian pesan melalui media massa, dimana pesan tersebut bisa menjangkau semua orang yang menggunakan media tersebut (Effendy, 2008: 50). Secara sederhana, komunikasi massa merupakan proses komunikasi dilakukan secara serentak, dengan melalui media massa. Terdapat perbedaan dalam komunikasi massa yang begitu signifikan dari jenis-jenis komunikasi lainnya. Perbedaan yang signifikan tersebut terletak pada umpan balik. Adapun komunikasi massa memiliki fungsi informasi, pendidikan dan mempengaruhi. Komunikasi massa tidak akan terjadi jika tidak ada media yang menjadi perantara antara komunikator dan komunikannya. Maka dari itu, komunikasi memiliki media sebagai perantaranya. Dalam kerangka behaviorisme, media massa adalah faktor lingkungan yang mengubah perilaku khalayak melalui proses pelaziman klasik, pelaziman operan, atau proses imitasi (belajar sosial). Khalayak sendiri dianggap sebagai kepala kosong yang siap untuk menampung seluruh pesan komunikasi yang dicurahkan kepadanya (Rakhmat, 2011: 200). Media massa digunakan untuk menjadi perantara antara komunikator dan khalayak luas, untuk memberikan informasi secara serentak.

\section{Media Massa Populer}


(ANALISIS NARASI TZVETAN TODOROV PADA FILM HABIBIE \& AINUN)

Film disebut sebagai sebuah media massa populer saat ini karena sebuah film merupakan sebuah penggabungan antara penglihatan dan pendengaran dimana pesan pesan yang disampaikan bisa diserap melalui suara yang disertai penggambaran adegan. Dalam (Sobur, 2014: 127) menjelaskan bahwa film bisa mempengaruhi khalayak atau penontonnya karena kemampuan dan kekuatannya dalam menjangkau segmen sosial. Isi pesan dari sebuah film dapat mempengaruhi dan membentuk sebuah masyarakat dari apa yang diceritakan dalam film tersebut namun tidak bisa berlaku sebaliknya. Sedangkan menurut Himawan Pratista (2008: 1) sebuah film terbentuk dari dua unsur, yaitu unsur naratif dan unsur sinematik. Unsur naratif meiliki hubungan dengan aspek cerita atau tema film. Setiap film cerita tidak mungkin lepas dari unsur naratif dan setiap cerita pasti memiliki unsur-unsur seperti tokoh, masalah, konflik, lokasi, waktu, serta lainnya-lainnya. Seluruh elemen tersebut membentuk unsur naratif secara keseluruhan. Aspek kausalitas bersama unsur ruang dan waktu merupakan elemen-elemen pokok pembentuk suatu narasi.

\section{Nasionalisme Dalam Film Indonesia}

Tahun 1980an merupakan era dimana sebuah film Indonesia meningkat begitu pesat dari tahun-tahun sebelumnya. Tercatat lebih dari 700 film hasil produksi yang sebelumnya berjumlah 604 film. Segala tema film masuk ke jajaran bioskop hingga jumlah penonton yang juga membludak. Namun, dari semua tema film tersebut, film pengkhianatan G30SPKI merupakan salah satu hal yang monumental dari jumlah penontonnya. Jumlah penonton film tersebut mencapai 699. 282 mengalahkan semua film-film yang tayang pada masa yang sama. Film ini juga menjadi salah satu pionir tentang film yang bertemakan patriotisme dan nasionalisme. Indonesia sendiri memiliki sejarah panjang tentang perfilman salah satunya film yang bertemakan nasionalisme. Hal ini di dasari dari sejarah bangsa Indonesia sendiri yang dulunya pernah dijajah dan merdeka karena usahanya sendiri (Sutadi, 2009).

Pada prinsipnya, jiwa nasionalisme adalah jiwa patriotism. Keduanya muncul dari rasa cinta. Hanya saja arahnya yang berbeda. Jika patriotism lebih terarah kepada tanah air, nasionalisme lebih terarah kepada sesama bangsa. Kedua hal tersebut sama-sama merasakan rasa sepenanggungan terhadap kelangsung hidup tanah air dan bangsanya (Abdulgani, 1998: 121). Meskipun manifestasi ideologi nasionalisme dalam proses sejarah menunjukan berbagai variasi, namun pada hakikatnya nasionalisme memuat beberapa prinsip, antara lain: 1) Kesatuan (unity), yaitu memiliki sifat kekeluargaan dan jiwa gotong royong dalam membangun kesejahteraan masyarakat. 2) Kebebasan (liberty, freedom), yaitu keleluasan sebagai warga negara dalam memilih haknya (tanpa adanya berbagai paksaan dari pihak masyarakat atau pemerintah), 3) Kesamaan (equality), memiliki keselarasan dan adil dalam kedudukan hukum, hak dan kewajiban, 4) Kepribadian (personality) atau identitas (identity), yaitu 
memiliki rasa bangga terhadap kepribadian dan identitas bangsanya yang tumbuh dari dan sesuai dengan sejarah dan kebudayaannya; 5) Prestasi (archivement), yaitu cita-cita untuk mewujudkan kesejahteraan dari bangsanya (Kartodirdjo, 1992:16).

\section{Analisis Narasi Dalam Film}

Narasi terdiri atas empat macam jenis: (1) narasi menurut Todorov, yang memiliki alur awal, tengah dan akhir, (2) menurut Propp, suatu cerita yang memiliki karakter tokoh, (3) menurut Levis-Strauss, cerita yang memiliki sifat-sifat berlawanan, (4) dan narasi Joseph Campbell, narasi cerita yang terkait dengan mitos (Branston dan Stafford 2003: 56-57). Keempat macam narasi tersebut bisa menjelaskan mengenai pesan apa yang disampaikan dalam sebuah cerita. Narasi merupakan sebuah cara bagaimana sebuah cerita yang disampaikan melalui media bisa dimengerti orang banyak. Narasi sendiri tidak berkaitan dengan fakta dan fiksi. Narasi hanya berkaitan dengan cara bercerita, bagaiamana sebuah fakta disajikan dan diceritakan kepada khalayak. Penggunaan analisis narasi memiliki beberapa kelebihan diantaranya, bagaimana sebuah pengetahuan, makna dan nilai diproduksi dan disebarkan dalam masyarakat. Sebuah cerita akan mudah di mengerti dan menarik tergantung dari pembawaan cerita tersebut. Apakah cerita tersebut akan memiliki cerita yang sulit ditebak atau sebaliknya. Kedua, kelebihan penggunaan analisis narasi akan memperlihatkan kepada pembaca atau penonton bagaimana situasi sosial politik diceritakan dalam pandangan tertentu yang dapat membantu kita mengetahui kekuatan dan nilai sosial yang dominan dalam masyarakat (Jacobs, 2007). Lalu yang ketiga, sebuah narasi memungkinakan seseorang untuk menyelidiki hal-hal yang tersembunyi yang terdapat dalam cerita. Peristiwa-peristiwa yang disajikan dalam bentuk cerita dan dalam cerita tersebut sebenarnya ada nilai-nilai dan ideology yang ingin di tonjolkan oleh pembuat cerita. Terakhir adalah bagaimana sebuah narasi bisa merefleksikan kontiunitas dan perubahan komunikasi (Frank, 2002) Hal tersebut menjelaskan bahwa ada beberapa cerita yang sama diceritakan dengan narasi yang berbeda dari satu waktu ke waktu lain. Perubahan narasi tersebut menggambarkan kontiunitas atau perubahan-perubahan nilai yang terjadi di dalam masyarakat. Dalam menyampaikan sebuah cerita, penulis tentu saja secara sadar menuliskan tahapan bagaimana cerita tersebut akan disampaikan. Susunan tersebut meliputi struktur-struktur tertentu yang bisa membuat pembaca ataupun penonton menjadi tertarik. Tzvetan Todorov mengemukakan bahwa seorang penulis disadari atau tidak menyusun teks atau cerita ke dalam tahapan struktur cerita tersebut (Eryanto, 2014).

\section{Analisis Narasi Tzvetan Todorov}

Tzvetan Todorov mengemukakan bahwa seorang penulis disadari atau tidak menyusun teks atau cerita ke dalam tahapan struktur cerita tersebut. Menurut Todorov, sebauh narasi memiliki struktur dari awal hingga akhir. Dimulai dari adanya keseimbangan yang kemudian terganggu oleh adanya masalahmasalah yang timbul dalam cerita. Alur 
(ANALISIS NARASI TZVETAN TODOROV PADA FILM HABIBIE \& AINUN)

ditandai oleh puncak atau klimaks dari perbuatan dramatis dalam rentang laju narasi.

(Eryanto, 2014)

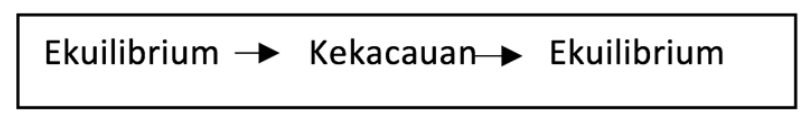

Gambar 1

Struktur narasi (Eryanto, 2014)

\section{METODE PENELITIAN}

Penelitian ini merupakan penelitian kualitatif dengan menggunakan metode penelitian deskriptif. Penelitian ini menggunakan pendekatan kualitatif karena pendekatan atau metode ini merupakan sebuah metode penelitian yang naturalistik karena penilaiannya dilakukan pada kondisi alamiah (natural setting) (Sugiyono, 2007: 8). Dalam penelitian ini, peneliti menggunakan paradigna konstruktivisme. Paradigma konstruktivisme. Konstruktivisme memiliki asumsi individuindividu selalu berusaha memahami dunia dimana mereka hidup dan bekerja.

\section{HASIL DAN PEMBAHASAN}

Berdasarkan uraian penelitian diatas, dapat dilihat bahwa terdapat beberapa fase yang menandai narasi cerita dalam film. Tzvetan Todorov mengemukakan bahwa struktur narasi terbagi menjadi tiga alur dengan ditandai oleh fase ekuilibrium - kekacauan - ekuilibrium. Lalu teori tersebut berkembang dengan modifikasi dari para ahli yaitu Nick Lacey dan Gillespie (Eryanto, 2014). Modifikasi teori tersebut mengemukakan indikator-indikator antara proses menuju atau akhir dari kekacauan yang terjadi dalam narasi yang dikemukakan Tzvetan Todorov sebelumnya. Maka peneliti melihat film Habibie \& Ainun memiliki kesesuaian terhadap teori yang di kemukakan oleh Tzvetan Todorov mengenai struktur narasi. Pada film Habibie \& Ainun ini juga peneliti memiliki fokus penelitian mengenai nasionalisme pada narasi cerita awal, tengah dan akhir cerita. Peneliti telah memaparkan pada analisis penelitian melalui sub-sub bab sebelumnya, agar dapat mudah dipahami.

Nasionalisme yang terlihat pada narasi awal film adalah prinsip nasionalisme kepribadian dan presetasi. Prinsip kepribadian ditunjukan oleh sikap Habibie yang sedang sakit namun mempunyai keinginan untuk membangun bangsanya. Habibie menulis sumpah dan janjinya untuk Indonesia. Hal tersebut merupakan sebuah tanggung jawab Habibie karena ia sebagai orang Indonesia yang berkuliah di Jerman harus kembali dan membangun bangsanya sendiri.

Pada narasi cerita awal film Habibie \& Ainun terdapat unsur kepribadian yang terjadi dalam film. Unsur kepribadian terjadi pada alur awal film berupa keinginan dan perjuangan Habibie melawan sakitnya untuk membangun Indonesia. Ketika sedang sakit Habibie menuliskan sebuah surat yang berisi sumpah dan janjinya untuk Indonesia. 
Scene menit 00.20.00-00.21. 13

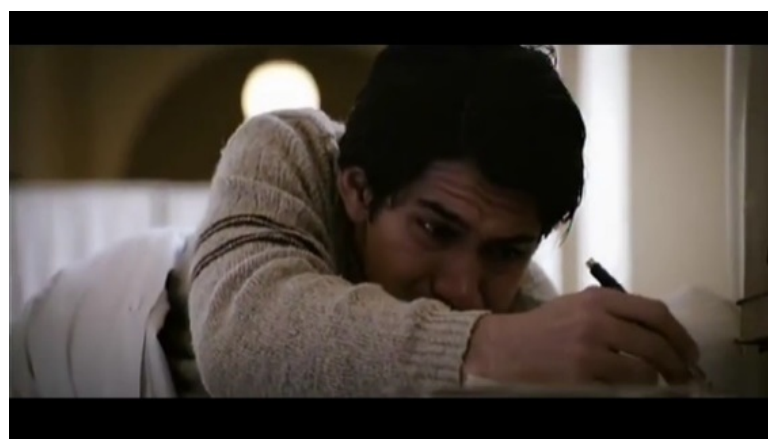

Habibie : "Sumpahku.

Terlentang. Jatuh. Perih. Kesal.

Ibu Pertiwi. Engkau pegangan.

Dalam perjalanan.

Janji pusaka dan sakti. Tanah tumpah darahku.

Makmur dan Suci. Hancur badan. Tetap berjalan. Jiwa besar dan suci.

Membawa aku, padamu"

Hal ini merupakan sebuah kepribadian tentang seseorang yang merasa bertanggung jawab untuk sembuh agar bisa berbuat sesuatu kepada bangsanya. Habibie menuliskan janji diselembar kertas tersebut sambil meneteskan air mata. Pada narasi cerita awal film Habibie \& Ainun terdapat unsur prestasi. Hal ini ditunjukan dari kesuksesan Habibie menyelesaikan proyek rangkaian kereta apinya sekaligus menyelesaikan gelar S3. Habibie mendapat pengkuan dari para tim yang berada di Jerman.

Prinsip yang kedua ialah prestasi yang ditunjukan dari capaian Habibie atas proyek rangkaian kereta apinya. Kesuksesan proyek rangkaian kereta api membuat Habibie memperoleh gelar doktor sekaligus mendapat pengakuan di Jerman. Prestasi yang ia capai merupakan sebuah awal dari janji dia untuk membangun Indonesia.
Scene menit 00:37:59-00:38:30

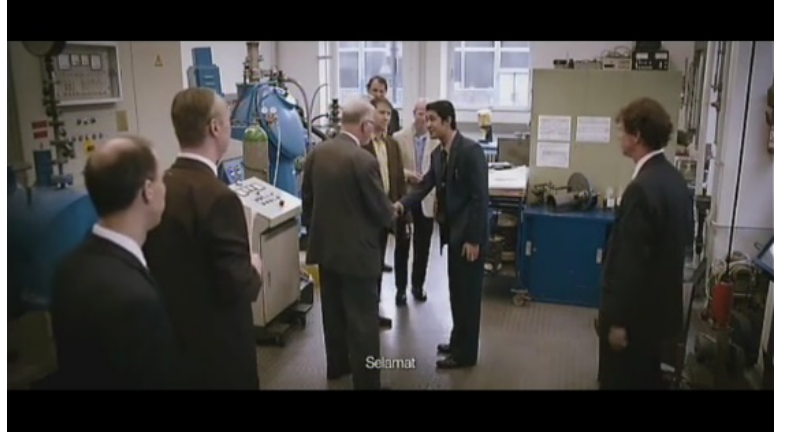

Anggota Tim : "Lihat, sekarang materinya terlihat kembali seperti semula"

Habibie : : "Ya, tentu saja. Karena semua tekanan masih dalam daerah elastisitasnya"

Anggota Tim : "Selamat"

Anggota Tim : "Aku tidak menyangka dia sejenius ini"

Nasionalisme di dalam narasi cerita tengah film Habibie \& Ainun meliputi keseluruhan prinsip yaitu kesatuan, kepribadian, kesamaan, kebebasan dan prestasi. Prinsip kesatuan ditunjukan dari pidato Habibie didepan audiens saat merencanakan proyek pesawat terbangnya. Pidato Habibie menunjukan bahwa ia memiliki prinsip kesatuan. Kesatuan akan bangsa Indonesia melalui presentasi mengenai industry strategis yang ingin ia buat. Industri strategis seperti pesawat, kereta api dan kapal container akan membuat orang-orang dengan mudah sehingga tercapainya kesatuan di Indonesia.

Prinsip kesatuan pada alur tengah film juga ditunjukan dari pidato Habibie dalam mempresentasikan rencana proyek pesawat terbangnya. Habibie dipanggil ke Indonesia untuk mewujudkan mimpinya membuat pesawat padahal sebelumnya Habibie sempat di tolak karena industri Indonesia dianggap belum 
perlu. Habibie memberikan presentasi

dihadapan audiens yang merupakan timnya.

Scene menit 00:48:12-00:48:55

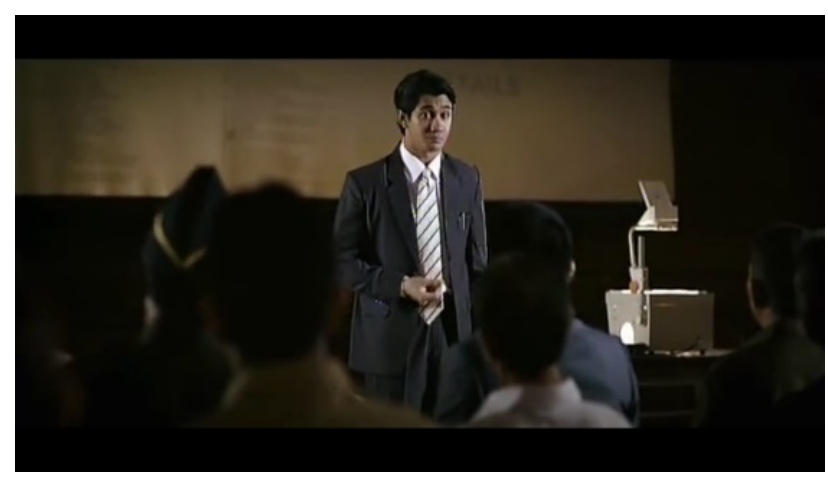

Habibie : "Kita harus mengembangkan industri strategis. Itu penting. Pesawat terbang, untuk menghubungkan antar pulau di Indonesia sebagai alat transportasi. Lalu kita juga membutuhkan kereta api. Kapalkapal besar untuk perdagangan dan container serta menyalurkan barangbarang antar pulau. Ini semua, merupakan buatan anak bangsa Indonesia. Kita manfaatkan mereka kita buka potensi mereka, sebagai generasi muda, meningkatkan kualitas hidup rakyat Indonesia."

Kesatuan akan bangsa Indonesia melalui presentasi mengenai industry strategis yang ingin ia buat. Industri strategis seperti pesawat, kereta api dan kapal container akan membuat orang-orang dengan mudah sehingga tercapainya kesatuan di Indonesia.

Prinsip kepribadian dalam narasi cerita tengah film Habibie \& Ainun ditunjukan dari sikap Ainun yang mengizinkan suaminya untuk memenuhi panggilan negara. Habibie yang ketika itu dipanggil ke Indonesia untuk membuat pesawat, dengan rasa sedih harus meninggalkan Ainun di Jerman bersama kedua anaknya.

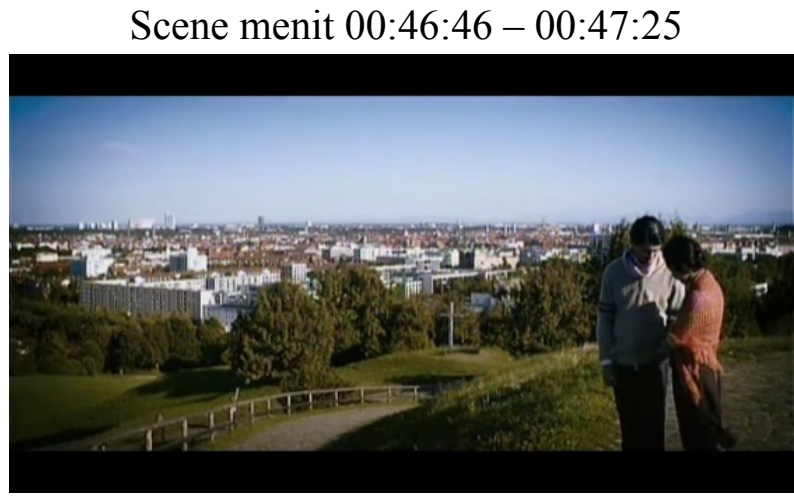

Habibie : "Saya harus kembali ke Indonesia dan membangun sebuah rencana pekerjaan. Butuh waktu yang lama. Dan harus meninggalkan kamu"

Ainun : "Bukan meninggalkan. ."

Habibie : "Ya tapi kamu akan repot mengurusi anak-anak. Saya gamau ganggu pekerjaan kamu"

Ainun : "Indonesia memanggilmu, pah. Bersyukurlah. Ini amanah yang besar.

Habibie : "Ya, ini saatnya"

Prinsip ketiga yang muncul adalah prinsip kesamaan pada narasi cerita tengah film. Hal tersebut ditunjukan dari dialog antar Habibie dan pengusaha Suhadi. Hal ini sebagai bentuk adanya kesamaan bahwa setiap orang yang ingin mengikuti proyek harus mengajukan proposal atau mengikuti tender.

Scene menit 01:00:39-01:01:06

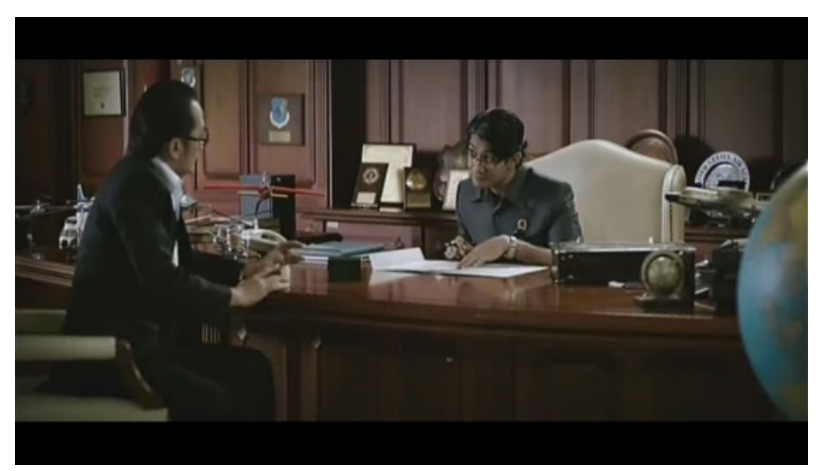


Habibie : "Ini (jam tangan) waktu itu ada yang tertinggal."

Suhadi : "Oh, ini tidak tertinggal. Ini memang buat Bapak."

Habibie : "Saya tidak bisa terima."

Suhadi : "Kenapa tidak? Oh maafkan. Memang ini belum, ga seberapa."

Habibie : "Pak Hadi begini, kalo Anda mau mengikuti sesuatu, anda bisa mengajukan saya proposal. Kalo anda mau ikut proyek, anda bisa mengikuti tender."

Scene menit 01:03:56 - 01:04:17

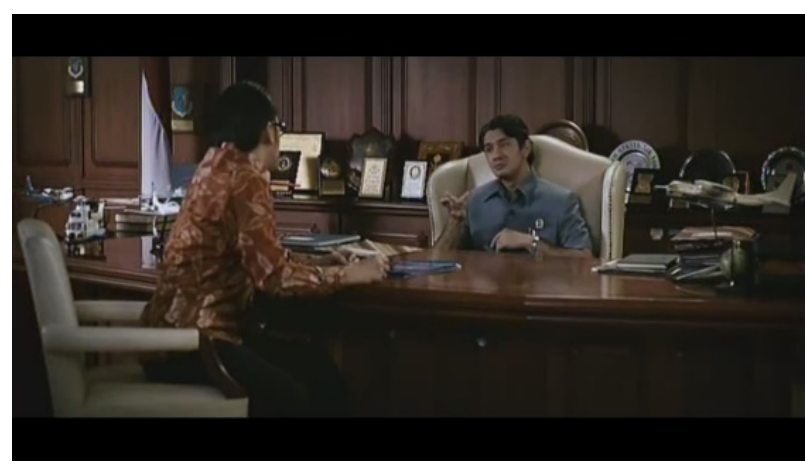

Suhadi : Jujur kedatangan saya kesini sebenernya saya ingin menawarkan sebuah kerjasama. Kerjasama pengadaan bahan pesawat terbang untuk IPTN. Saya bisa melihat bahwa program bapak ini akan sukses dan menyumbang pembangunan bangsa Indonesia."

Habibie : "Tapi saya sudah pernah bilang sama anda, kalo anda mau, anda bisa ikut tender."

Keempat, di dalam narasi cerita tengah film Habibie \& Ainun ini adalah prinsip kebebasan. Hal ini ditunjukan dari ide Habibie untuk menyurati industri penerbangan Indonesia agar ia bisa pulang untuk membuat pesawat untuk Indonesia. Habibie yang ingin mengabdikan diri untuk membuat pesawat bagi Indonesia. Habibie menuliskan surat untuk industri penerbangan di Indonesia agar ia bisa pulang untuk mengabdi pada Indonesia.

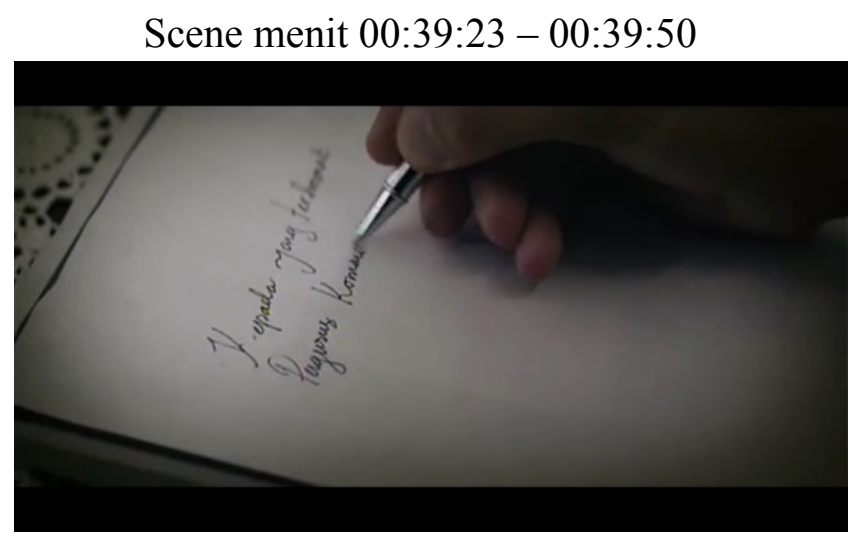

Habibie : "Kepada Yang Terhormat. Pengurus Komando Industri Pesawat Terbang di Indonesia.

Saya B. J Habibie telah menyelesaikan pendidikan S3. Saya ingin kembali ke Indonesia dan mengabdikan diri saya membuat pesawat terbang untuk Indonesia”

Lalu adanya prinsip nasionalisme yang terakhir pada alur tengah film ini adalah prestasi. Prestasi tersebut ditunjukan oleh Habibie dan anak-anak bangsa Indonesia pembuat pesawat. Pesawat yang mereka telah selesai dan sukses pada penerbangan perdananya. Terlebih pesawat itu merupakan pesawat yang dibuatkan untuk Indonesia sendiri dan dibuat oleh anak-anak bangsa sendiri.

Prinsip nasionalisme prestasi atau penghargaan bagi seseorang untuk bangsanya. Hal tersebut ditunjukan ketika wawancara Habibie dengan media dalam prestasi Indonesia yang sedang membuat pesawat terbangnya sendiri. Prestasi lainnya juga ketika pemberitaan mengenai penerbangan perdana pesawat N250 buatan Habibie. Penerbangan perdana pesawat N250 berhasil dan sukses yang membuat 
(ANALISIS NARASI TZVETAN TODOROV PADA FILM HABIBIE \& AINUN)

Habibie menjadi orang pertama yang membuat pesawat bagi Indonesia.

Scene menit 01:05:37 - 01:05:54

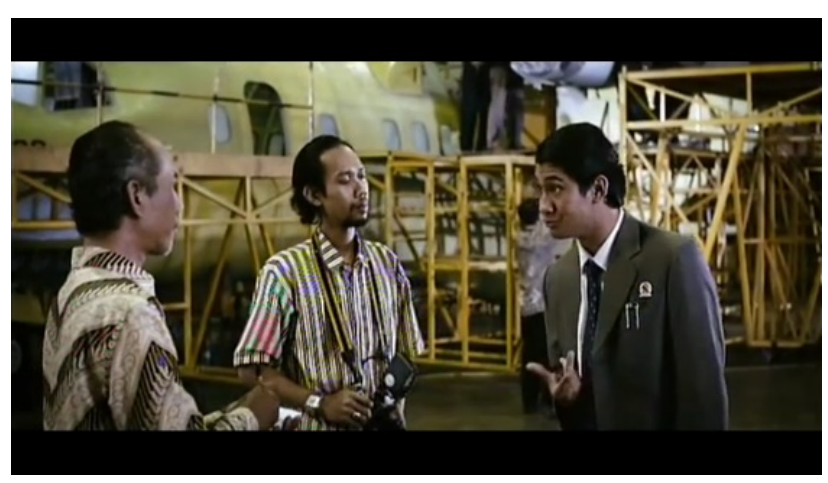

Wartawan : "Jadi Indonesia sudah bisa bikin pesawat sendiri ya Pak?"

Habibie : "Ya ini begini ya. Ini bukan sekedar lagi kami bisa membuat sendiri. Ini sudah mampu untuk membuat pesawat sendiri. Ini kan sudah menjadi bukti. Yang paling penting adalah anda bisa lihat sendiri ini, dikerjakan oleh anakanak bangsa Indonesia"

Scene menit 01:10:49-01:11:35

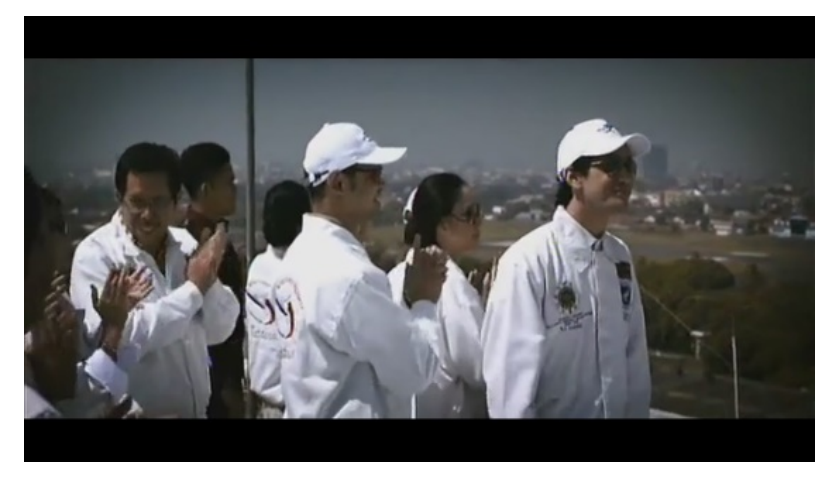

VO berita : "Terbayar sudah kerja keras anakanak bangsa kita menyaksikan penerbangan pesawat N250 ini. Sekarang bangsa Indonesia mempunyai pesawat terbang sendiri. Kita sudah bisa membuktikan pada dunia bahwa anak-anak bangsa Indonesia sudah mampu membuat pesawat sendiri”
Nasionalisme dalam narasi cerita akhir film Habibie Ainun meliputi prinsip kesatuan dan kepribadian. Prinsip kesatuan dalam alur akhir ini di tunjukan dalam percakapan antara Habibie dengan Ainun di hangar tempat pesawat N250. Habibie mengatakan bahwa pesawat ini nantinya akan bisa menghubungkan dan manyatukan pulau-pulau di Indonesia.

Pada narasi cerita akhir cerita film Habibie \& Ainun terdapat prinsip nasionalisme yang terkandung yaitu prinsip kesatuan. Prinsip ini ditunjukan oleh dialog Habibie dengan Ainun tentang manfaat pesawat yang ia buat untuk masa depan Indonesia.

Scene menit 01:28:43 - 01:29:

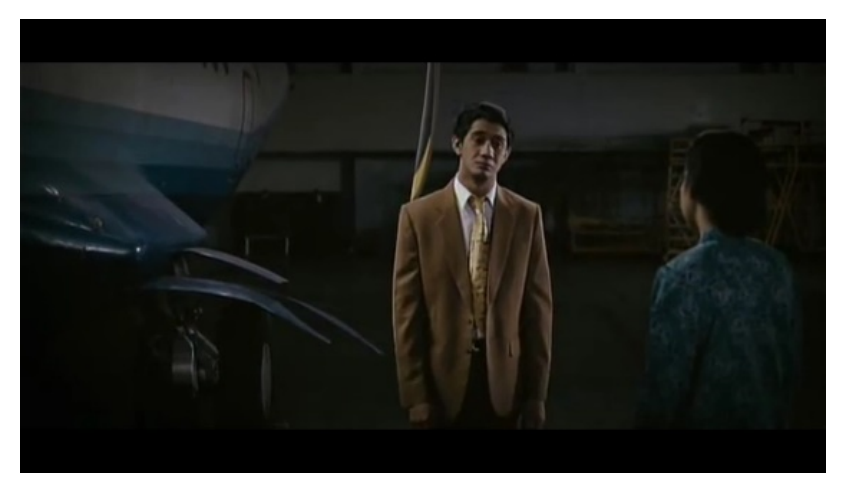

Habibie : "17 ribu pulau Ainun. 17 ribu. Kamu bisa bayangkan bagaimana kalau pesawat ini kemudian menghubungkan seluruh bagian Indonesia. Murah, aman, akan banyak infrastruktur yang bisa berkembang, ekonomi yang mekar, bangsa ini bisa menjadi bangsa yang mandiri. Tapi mereka tidak pernah percaya.

Selanjutnya prinsip nasionalisme yang terjadi di dalam alur akhir adalah prinsip kepribadian. Hal ini ditunjukan dari sikap Habibie yang teguh akan pendiriannya. Habibie rela untuk tidak tidur karena tanggung jawabnya 
sebagai presiden. Pada tahun 1999 merupakan tahun yang berat bagi Indonesia karena pada saat itu Timor Timur melepaskan diri dari Indonesia. Sehingga Habibie mengerahkan seluruh tenaga dan pikirannya untuk menyelesaikan masalah yang terjadi.

Pada narasi cerita akhir film Habibie \& Ainun terdapat prinsip kepribadian. Hal ini ditunjukan oleh sikap Habibie yang selalu tidur larut malam untuk mengerjakan pekerjaannya.

Scene menit 01:23:27-01:25:33

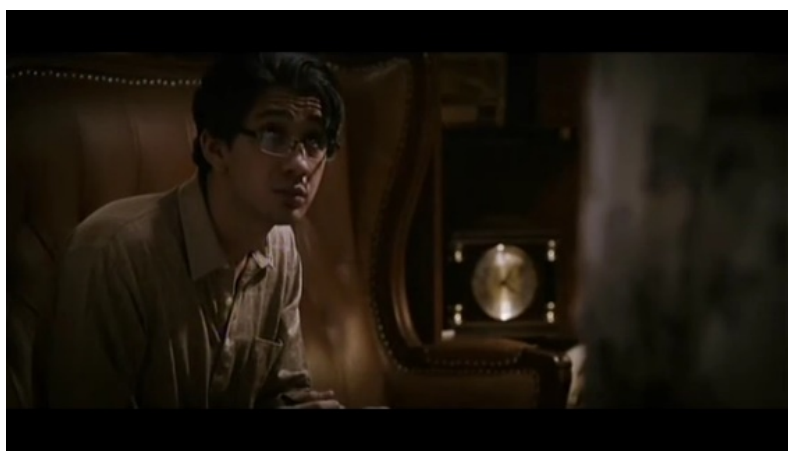

Habibie : "Saya harus buat analisa penting. Kamu bisa tidur lebih dulu"

Ainun : "Pah. . pah!"

Habibie : "Sebentar mah"

Ainun : "Du bist nie Superman"

Habibie : "Ya tapi ini harus segera saya selesaikan, tidak bisa ditunda lagi. Saya harus segera temukan solusinya"

\section{SIMPULAN}

Film Habibie \& Ainun merupakan sebuah film yang mengandung prinsip nasionalisme yang dikemukakan menurut Sartono Kartodirjo. Prinsip nasionalisme tersebut antara lain kesatuan, kebebasan, kesamaan, kepribadian dan prestasi. Berdasarkan narasi cerita awal film, film Habibie \& Ainun mengandung prinsip nasionalisme yaitu prinsip kepribadian dan prestasi. Prinsip kepribadian ditunjukan dari sikap seorang Habibie yang berjuang melawan sakit namun bersumpah dan tetap berjanji untuk membangun Indonesia. Habibie menuliskan sebuah sumpah dan janjinya disebuah kertas hingga Habibie meneteskan air mata. Prinsip prestasi pada narasi cerita alur awal, ditunjukan dari kesungguhan Habibie dalam mengerjakan proyek yang akan membawa dia meraih gelar doktor. Kesuksesan proyeknya tersebut membuat Habibie di akui di Jerman. Dengan gelar tersebut Habibie akan lebih mudah untuk kembali ke Indonesia dan membangun Indonesia.

Berdasarkan narasi cerita tengah film, film Habibie \& Ainun mengandung seluruh prinsip nasionalisme yaitu kesatuan, kepribadian, kesamaan, kebebasan dan prestasi. Prinsip kesatuan ditunjukan dari pidato Habibie saat akan mempresentasikan rencana pekerjaan pesawat terbangnya. Dalam pidato tersebut Habibie menyampaikan mengenai manfaat industri strategis yaitu untuk menghubungkan dan menyatukan pulau-pulau di Indonesia. Prinsip kedua yaitu prinsip kesamaan ditunjukan dari percakapan antara Habibie dan pengusaha Suhadi. Habibie mengatakan kepada Suhadi bahwa jika ingin mengikuti proyek, Suhadi bisa mengajukan proposal seperti yang lain. Prinsip ketiga yaitu prinsip kepribadian yang ditunjukan oleh sikap Habibie yang menolak uang suap dari pengusaha Suhadi. Pada saat itu Habibie menolak hadiah berupa uang satu koper yang diberikan oleh Suhadi. Prinsip selanjutnya ialah prinsip kebebasan, Habibie menuliskan surat untuk pemerintah 
Indonesia bahwa ia siap untuk mengabdikan dirinya membangun Indonesia. Habibie melakukan kebebasan berpendapat dengan menuliskan surat kepada pemerintah. Prinsip yang terakhir yang ada dalam narasi cerita tengah film yaitu prestasi. Prestasi ditorehkan Habibie dan anak-anak bangsa lainnya saat berhasil dan sukses membuat pesawat terbang.

Berdasarkan narasi cerita akhir film, film Habibie \& Ainun mengandung prinsip nasionalisme yaitu prinsip kesatuan dan kepribadian. Prinsip kesatuan ditunjukan dari percakapan Habibie dengan Ainun di hangar pesawat IPTN Bandung. Habibie mengatakan hal yang sama sewaktu ia berpidato saat merencanakan proyek pesawat terbangnya. Bahwa pesawat ini nantinya bisa mempersatukan Indonesia, dan Indonesia akan menjadi bangsa yang mandiri. Lalu, prinsip kepribadian ditunjukan oleh sikap Habibie yang tidak tidur demi mengerjakan pekerjaannya sebagai presiden. Habibie bekerja semalam suntuk untuk menganalisis masalah yang terjadi pada saat itu.

Adapun saran dari peneliti, diharapkan peneliti selanjutnya untuk terus mengkaji penelitian tentang analisis pada media massa khususnya film baik menggunakan metode analisis narasi maupun analisis lainnya untuk menambah referensi bagi penelitian bagi studi media. Penggunaan film sebagai media penelitian dikarenakan sebuah film merupakan sebuah perpaduan audio visual yang mudah dimengerti dan menarik untuk menyampaikan sebuah informasi. Film juga merupakan sebuah gambaran dari realita sosial yang ada di masyarakat sehingga diharapkan dengan mudah mengkaitkan antara fakta dan teori yang ada. Pada bidang Praktis, film yang mengandung dan bertemakan nasionalisme seperti film Habibie \& Ainun merupakan sebuah film yang cukup menarik karena selain bisa membuat penonton terhibur, film ini juga bisa meningkatkan nasionalisme yang ada di dalam diri. Struktur narasi yang digunakan juga menunjukan bahwa film Habibie \& Ainun memiliki narasi yang cenderung sama bagimana keteraturan awal pada narasi akan kembali juga ke dalam keteraturan awal. Untuk para sineas perfilman, film Habibie \& Ainun bisa menjadi contoh bagaimana sebuah film bisa menghibur dan memberi manfaat yang bisa mencerahkan bagi penontonnya.

\section{DAFTAR PUSTAKA}

Abdulgani, Roeslan. 2002. Nasionalisme Asia. Jakarta: Prapantja

Effendy, Onong Uchjana. 1986. Dinamika Komunikasi. Bandung: Penerbit Remadja Karya

Eriyanto. 2014. Analisis Naratif: Dasar-dasar dan penerapannya dalam Analisis Teks Berita Media. Jakarta: Kencana Prenada Media Group.

Frederick Hertz, 2004. Nationality In History and Politics (1944). City Central Library, Hyderabad, No. 82869

Film Indonesia. 2016. Data Penonton. Diakses dari situs 
ProTVF, Volume 2, Nomor 1, Maret 2018, Hal. 37-49

http://filmindonesia.or.id/movie/viewer/2

016. Pada tanggal 27 September 2016.

Gill Branston and Roy Stafford. 2003, The Media Student's Book

Kartodirdjo, Sartono. 1992. Pendekatan Ilmu Sosial dalam Metodologi Penelitian Sejarah. Jakarta: PT Gramedia Pustaka Utama.

Pratista, Himawan, 2008. Memahami Film. Yogyakarta: Homerian Pustaka.

Rakhmat, Jalaluddin. 2011. Psikologi Komunikasi. Bandung: Remaja Rosdakarya
Senova, Annisa. 2012. Literasi Media Sebagai Strategi Komunikasi Tim Sukses Relawan Pemenangan Pemilihan Presiden Jokowi Jk Di Bandung. Jurnal Kajian Komunikasi 4. 2. Diakses dari http://jurnal.unpad.ac.id/jkk/article/vi ew/7411

Sobur, Alex. 2014. Ensiklopedia Komunikasi. Bandung: Remaja Rosdakarya.

Sugiyono. 2007. Memahami Penelitian Kualitatif, Bandung: Alfabeta.

Sutadi, Heru. 2009. Sejarah Perkembangan Film Indonesia. Diakses dari http://herusutadi.blogdetik.com/2009/10/ 12/sejarah-perkembangan-filmindonesia/. Pada tanggal 27 September 2016 